\title{
PodeM OS PERSONAGENS SECUNDÁRIOS FALAR? \\ POSIÇÃO FEMININA NO DOCUMENTÁRIO AUTOBIOGRÁFICO FACE À MEMÓRIA DA DITADURA MILITAR NO BRASIL
}

CAN THE SECONDARY CHARACTERS TALK?

FEMALE POSITION IN THE AUTOBIOGRAPHICAL

DOCUMENTARY FACE WITH THE MEMORY OF THE

MILITARY DICTATORSHIP IN BRAZIL

Ilana Feldman

Universidade de São Paulo

São Paulo - Brasil

\section{Resumo}

Diante do campo da autobiografia e de seu cruzamento com o cinema, no contexto da experiência legada pela ditadura civil-militar brasileira, este artigo pretende investigar certos modos políticos de enunciação e subjetivação, aqui postos em cena pelos documentários autobiográficos "Os dias com ele" (Brasil, 2012), de Maria Clara Escobar, e "Diário de uma busca”, de Flávia Castro (Brasil, 2011). Nessas obras, realizadas por filhas de exilados e presos políticos, estão em jogo duas formas distintas de posição feminina e de busca pela figura paterna, nas quais coexistem exílio, memória, testemunho e até mesmo a disputa pelo filme que está sendo feito. Face ao problema do lugar secundário das filhas diante das utopias políticas dos pais, no contexto da experiência do fracasso das esquerdas no Brasil, "Os dias com ele" e "Diário de uma busca" propóem uma passagem do privado ao político, do pai ao país, a partir de uma ética da precariedade.

Palavras-chave: posição feminina, documentário autobiográfico, exílio; disputa, precariedade.

\begin{abstract}
At the crossroad of the autobiographic genre and cinema in the context of the legacy of Brazilian civil-military dictatorship, this article aims to investigate singular modes of enunciation and subjectivation as staged by two autobiographical documentaries: "Os dias com ele" (Brazil, 2012), by Maria Clara Escobar, and "Diário de uma busca", by Flávia Castro (Brazil, 2011). Filmed by daughters of political exiles and prisoners,
\end{abstract}

\section{Résumé}

Face au champ de l'autobiographie et à son croisement avec le cinéma, dans le contexte de l'expérience héritée de la dictature civile-militaire au Brésil, cet article vise à étudier certains modes politiques d'énonciation et de subjectivation mis en scène ici par les documentaires autobiographiques "Os dias com ele” (Brésil, 2012), de Maria Clara Escobar, et "Diário de uma busca", de Flávia Castro (Brésil, 2011). Dans ces 
these works produce two different types of positions of a female in search of a paternal figure, in which exile, memory, testimony and even argument about the movie in progress coexist. Confronted with the problem of the daughter's secondary role in comparison to the father's politicals utopias, faced with the experience of the failure of the left in Brazil, "Os dias com ele" and "Diário de uma busca" propose a journey from the private to the political and from the father to the country through an ethics of precariousness.

Keywords: female position, autobiographical documentary, exile, argument, precariousness. œuvres menées par des filles d'exilés et des prisonniers politiques, deux différentes formes de position féminine et de la quête de la figure paternelle sont en jeu où l'exil, la mémoire, le témoignage et même le conflit autour du film en cours coexistent. Confronté au problème du rôle secondaire des filles par rapport aux utopies des pères, face à l'expérience de l'échec de la gauche au Brésil, "Os dias com ele" et "Diário de uma busca" proposent un passage du privé au politique, du père au pays, à partir d'une éthique de la précarité.

Mots-clés: position féminine, documentaire autobiographique, exil, conflit, précarité.

Hoje inventei esta piada: Quando crescer vou ser um personagem secundário, diz um menino a seu pai. Por quê?

Por que o quê? Por que você quer ser um personagem secundário? Porque o romance é teu.

Alejandro Zambra, Formas de voltar para casa

\section{Segunda geração}

Nunca um momento político brasileiro foi tão favorável à revisão de nossa ainda recente e hesitante democracia como o atual. Como se vê em filmes contemporâneos, parte expressiva dessa revisão vem sendo realizada por um cinema documental de cunho autobiográfico, cujo foco de investigação são as experiências pessoais e heranças históricas legadas pela ditadura civilmilitar brasileira (1964-1985). Filhas de pais exilados e presos políticos, as diretoras Maria Clara Escobar, em Os dias com ele (2013), e Flávia Castro, em Diário de uma busca (2011), lançam mão de formas distintas de busca pela figura paterna, busca na qual a infância, a experiência do fracasso e até a disputa pelo filme que está sendo feito não apenas coexistem como fazem a passagem do pai ao país, do privado ao político, da autobiografia a uma escrita marcada por forte presença da alteridade. 
Os dias com ele e Diário de uma busca são, portanto, solidários entre si: além de marcarem a estreia no longa-metragem de Maria Clara Escobar e Flávia Castro, elegem a relação com o pai e com a memória do pai, ambos militantes da luta armada brasileira, o eixo a partir do qual o período da ditadura civil-militar no Brasil é descortinado. Por meio de uma mirada pessoal e concretamente situada nas presenças performativas das diretoras (Maria Clara no antecampo a entrevistar Carlos Henrique Escobar, e Flávia Castro a narrar em voz off), é travado um embate com a história, a memória, nossa herança política e a experiência do exílio, seja o exílio de Celso Castro e de toda uma geração de militantes políticos da qual fez parte nas décadas de 1960 e 1970, seja o autoexílio solitário de Carlos Henrique Escobar na atualidade.

Tendo participado da resistência ao regime como intelectuais e integrantes de movimentos armados, o filósofo e dramaturgo Carlos Henrique Escobar e o jornalista Celso Castro, como muitos de seus companheiros, fracassaram em seus projetos revolucionários. Celso, pai de Flávia, morreu durante uma ação controversa em 1984, pós-anistia política no Brasil, dentro do apartamento de um suposto colaborador nazista na cidade de Porto Alegre. Após retornar do exílio político que o levou a morar em diversos países (Chile, Argentina, França, Venezuela), Celso não encontrou sentido no processo de abertura e redemocratização brasileira, visto por ele como um "fracasso", com a vitória dos militares, protegidos pelo esquecimento programado conferido pela Lei da Anistia (1979), e a derrota dos militantes. Já Carlos Henrique, pai de Maria Clara, extremamente crítico aos caminhos trilhados pela esquerda brasileira, desde 2002, ano do primeiro governo Lula, vive em exílio voluntário em Aveiro, uma pequena cidade de Portugal. Abandonou a filosofia e a dramaturgia, fazendo opção pelo recolhimento, pela solidão e pelo "absoluto anonimato".

As filhas, cada uma à sua maneira, ambas falando em nome próprio, na primeira pessoa do singular, decidem então tomar o cinema como um instrumento de embate, reconstrução da memória e reflexão. No caso de Maria Clara Escobar, essa reflexão que não teme o conflito é sobre o silêncio, "os silêncios históricos e pessoais", o silêncio da ditadura e, diz ela ao pai, "o silêncio que eu tenho na minha própria história com relação à sua”. Também Flávia Castro, narrando na primeira pessoa, faz do cinema um instrumento de reconstrução e reencontro entre a memória pessoal e a coletiva, a memória de seu pai e de seu país, porém mais atenta ao passado e à infância no exílio, evitando com isso encarar certos embates que se apresentam na atualidade, do filme e da vida, ou encarando esses embates de maneira imensamente delicada, do modo como é possível.

Os dias com ele, como o título já indica, se constrói a partir da imobilidade espacial e de um relativo confinamento (o filme não sai da casa 
de Carlos Henrique Escobar, quando muito vai ao quintal), realizandose no tempo presente da relação entre pai e filha, a qual o interroga, de maneira destemida, sobre seu passado, sua formação política e a experiência da tortura. Já Diário de uma busca, de forma completamente distinta, se constrói no deslocamento espacial, na busca por experiências passadas e no retorno à infância e adolescência de Flávia. $O$ passado é narrado no presente do indicativo, tanto por meio dos diários da Flávia-menina (quando o filme emprega planos fixos), como das cartas de Celso Castro aos filhos (quando o filme lança mão de travellings ou planos em movimentos). Aqui, a narradora está subjetivamente fixada no passado ("tenho seis anos", diz Flávia em certo momento), enquanto os questionamentos de Celso Castro recuperados em suas cartas ("ninguém quer entender que voltamos derrotados") valem tanto para o passado como para o presente da filmagem e atualidade do país, na forma de duros diagnósticos. Como se vê, através dessas duas formas narrativas de "diário", com temporalidades distintas, ambas as filhas inscrevem, na própria fatura fílmica, a ausência de seus pais. Em Os dias com ele, Carlos Henrique Escobar revela-se como uma presença ausente, um ser distante e formal, ainda que muito carismático, enquanto em Diário de uma busca Celso Castro é evocado sempre afetivamente, como uma ausência presente.

Representantes do trauma da segunda geração, a de filhas e filhos de militantes políticos que cresceram marcados pela ausência e pelo exílio, Maria Clara e Flávia seriam, como o narrador de Alejandro Zambra no romance Formas de voltar para casa, "personagens secundários" diante do olhar de pais mobilizados pelas grandes utopias políticas. Como tantas outras realizadoras, elas fazem parte de uma guinada autobiográfica bastante presente no documentário em primeira pessoa na América Latina, não por acaso realizado por mulheres. Esse é o caso de Los rubios, de Albertina Carri (Argentina, 2003), Papa Ivan, de Maria Inés Roqué (Argentina/México, 2004), Segredos de lucha, de Maiana Bidegain (Uruguai/França, 2007), Espeto de pau, de Renate Costa (Paraguai/Espanha, 2010), Familia tipo, de Cecília Priego (Argentina, 2009) ${ }^{1}$ e, mais recentemente, Iramaya, de Carolina Benjamin (Brasil, 2017) e Construindo pontes, de Heloísa Passos (Brasil, 2017), todos eles centrados na relação entre pais e filhas no contexto das ditaduras latinoamericanas.

Neste ponto, seria importante perguntar por que a autoria femininaque implica aqui uma posição feminina - se coloca de maneira tão expressiva nessas obras. Seria essa posição feminina o que permite às realizadoras se

1 Em 2014, Natália Barrenha e Pablo Piedras realizaram na Caixa Cultural São Paulo a mostra "Silêncios históricos e pessoais", importante panorama da produçāo latino-americana focada no documentário em primeira pessoa, onde pudemos ter acesso a esses filmes. Mais informaçôes em: <http://doctela.com. $\mathrm{br} /$ mostrasilencios/>. 
abrir aos embates com o passado e o presente? O que permite o diálogo e o encontro com o outro? $\mathrm{O}$ que permite uma passagem, como postulavam as feministas dos anos 1970, do pessoal ao político? Construídas de modo geral a partir de um não saber, de uma posição subjetiva e de uma enunciação fílmica que não obliteram sua precariedade, parcialidade e contingência, essas obras revelam imensa disposição e coragem. Mas, afinal, o que entendemos por "feminino"?

Poderíamos reconhecer aqui o feminino não como uma comunidade de origem determinada pelo gênero, mas como uma comunidade aberta ao destino, tal como o define Judith Butler (2003) e a psicanálise. O feminino, nesse sentido, não seria definido por uma anatomia, essência ou biologia, mas se constrói performativamente no âmbito social e cultural na forma de um compromisso com o porvir. No ensaio Vidas precárias (2016), a filósofa norte-americana propóe uma forma de politização que abandone a noção de pai ou de Estado como chancela ou garantia de nossas vidas, e que tenha como fundamento a "vulnerabilidade" e a "precariedade" presente em todos nós (disposiçóes historicamente reconhecidas como próprias ao feminino).

Como veremos mais detidamente em Os dias com ele, seguindo o apelo de Butler, reconhecer a precariedade de alguém não significa reconhecer a sua identidade, mas proteger sua possibilidade de futuro, de tornar-se algo que ainda não se sabe. $\mathrm{O}$ filme dura e belamente nos mostra: para haver futuro, é preciso haver coragem, coragem de quem, inclusive, não teme errar ou fracassar. Como escreve Maria Clara Escobar a propósito do processo de realização da obra: "Deixei de ter vergonha do erro e do descontrole, e se abriu uma porta enorme em minha vida" . Assim, a precariedade se torna a condição necessária para restituir, de forma narrativa, a experiência do fracasso político e do exílio tal como vivida pela segunda geração. Mas podem os personagens secundários falar? Serão eles de fato escutados?

\section{Disputa e distância}

- Eu não sei bem que filme é esse que você está fazendo. Eu tenho a impressão de que é um filme sobre você. Se for isso, é maravilhoso - diz Escobar a Maria Clara. - Os filmes sempre são sobre nós

- É por isso que você faz mais perguntas sobre você. Mas eu sou mais público, quer dizer, eu falo das questóes de fora...

- Mas não é só sobre mim. Eu tenho interesse...

- Ah, pega meu aparelho [auditivo]

$2 \mathrm{O}$ texto "Anotaçōes sobre um processo" acompanha o DVD do filme lançado pelo Instituto Moreira Salles em 2016. Em consonância com a realizadora, poderíamos nos lembrar da narradora de $A$ paixão segundo G.H, de Clarice Lispector, quando ela formula "(...) Pois só quando erro é que saio do que conheço e do que entendo" (1998, p.109). 
- Mas é também uma reflexão sobre os silêncios, os silêncios históricos e pessoais

- Eu estou tentando entender essa sua questão, eu não entendi. Seja corajosa e diga o que é. Porque se você tem que fazer as perguntas, já que tudo isso se refere a você, faça com coragem, se não fica ambíguo demais!

- É uma mistura para mim do silêncio da ditadura, do que aconteceu na ditadura, com o silêncio que eu considero que eu tenho na minha história com relação a sua história

- Já estamos começando?

- Podemos, só um minuto

Face à inflação de variadas estratégias de confissão pública, de testemunhos em nome próprio e de documentários autobiográficos narrados na primeira pessoa, manifestaçóes que compóem nosso atual e hipertrofiado "espaço biográfico" (ARFUCH, 2011), a ensaísta argentina Beatriz Sarlo, em seu provocador Tempo passado: cultura da memória e guinada subjetiva, adverte: "Se há três ou quatro décadas o 'eu' despertava suspeitas, hoje nele se reconhecem privilégios que seria interessante examinar" (2007, p.21).

É visando ao exame dos privilégios adquiridos pelas narrativas em primeira pessoa, consideradas fontes sempre mais autênticas, verdadeiras e legítimas, que se pode dizer que, diferentemente da febre autobiográfica e do teor confessional que dão a tônica da cultura atual, Os dias com ele é dotado de uma coragem: não evita o mal-estar, os desentendimentos e o desencontro, ao mesmo tempo em que assume a dificuldade de compreensáo, a precariedade dos meios e a opacidade da linguagem como elementos constitutivos não apenas das relaçôes familiares em jogo, mas sobretudo de sua matéria fílmica.

Mas o empreendimento não é fácil. Escobar, desgostoso com a derrocada das esquerdas brasileiras e tendo se exilado voluntariamente em Portugal há mais de uma década, optou pelo recolhimento e por uma vida rodeada de papéis e gatos. Para Maria Clara, tendo atravessado o oceano, o mais difícil está por vir. Ela quer desse pai, com quem tem uma relação difícil e distante, uma reflexão sobre o silêncio imposto pela ditadura e aquele que ela própria carrega em sua história. Escobar diz não entender: "Eu não sei bem que filme é esse que você está fazendo. Eu tenho a impressão de que é um filme sobre você. Se for isso, é maravilhoso", mas "seja corajosa!". Ao que ela lhe responde: "Os filmes são sempre sobre nós". E ele então justifica: "Mas eu sou mais público, eu falo das questōes de fora..."

Construído na tensão entre os âmbitos público e o privado, Os dias com ele é composto por testemunhos, entrevistas e conversas entre pai e filha, além da observação do cotidiano de Escobar e de filmes caseiros em Super-8 (os quais emprestam uma memória que a própria realizadora náo tem de sua infância), incorporando em sua fatura os momentos que antecedem e que sucedem essas conversas, como cacos de palavras, preparaçóes da cena, 
ensaios e mal-entendidos. Sáo sobretudo nesses momentos, mais próximos do que seria da ordem do processo ou do bastidor, nos quais Escobar não se sabe filmado (“já começou?", ele pergunta algumas vezes), que tanto a cena (a quem pertence o filme?) quanto a vida (quais posiçóes pai e filha ocupam?) aparecem em disputa.

Performando-se para a câmera, ensaiando e encenando conferências e discursos ("O Freud simulava”, justifica-se), Escobar quer roteirizar o filme da filha, quer ser construído e visto como um personagem importante e público. Já Maria Clara, presente sobretudo por meio de sua voz, a quem Escobar nunca chama de filha, faz questão de colocá-lo no lugar de pai, de personagem privado. Reivindicando seu testemunho pessoal sobre a tortura, Maria Clara jamais oferece ao espectador qualquer outra informação sobre Escobar (biografia, datas, feitos, obras publicadas) que não passe por aquilo que emerge no presente da relação entre os dois e na atualidade da filmagem. Escobar faz um teatro sobre ele; a filha responde com um filme sobre ela.

Mas não se trata aqui apenas de uma disputa mesquinha, fruto de vaidades inconfessáveis (ou já bastante confessadas, no caso de Escobar) e ressentimentos mútuos destilados. As vaidades e os ressentimentos existem e são explicitados, porém $O$ s dias com ele não se reduz, de forma alguma, a um acerto de contas familiar. Como escreve o crítico Jean-Louis Comolli, em "Como filmar o inimigo?": "Não se filma sem amor, sem desejo, sem inconsciente, sem corpo; mas também não se filma sem consciência, sem moral, sem cálculos, sem gostos e desgostos" (2008, p.129). A disputa é, portanto, interessantíssima e em nada mesquinha ou narcísica, fazendo das fraturas afetivas um lugar de confronto, mas também de vital encontro.

Se não se trata então de simplesmente afagar feridas e remorsos narcísicos, postura de alguns exilados (Said, 2003), a disputa em questão pela cena - e pelo filme - é uma disputa política entre a tarefa individual da narrativa do trauma (os vários traumas em questão) e sua componente coletiva; entre a memória do pai militante, o desconhecimento da filha e a história de um país; entre a extrema necessidade de seu testemunho (como "responsabilidade histórica"3, diz Maria Clara) e sua crônica impossibilidade, condição aporética de toda situação testemunhal diante da violência de Estado4. A disputa é, então, sobretudo, entre o espaço da “intimidade", modernamente considerado mais verdadeiro e autêntico do que o público,

3 A exigência do testemunho como responsabilidade histórica marca de maneira inaugural o projeto de Shoah (1985), monumental documentário de Claude Lanzmann, com nove horas de duração e composto grosso modo por testemunhos de sobreviventes dos campos de extermínio nazistas. Recusando as imagens de arquivo, por considerá-las perigosas e, ao mesmo tempo banais, sob o risco da manipulação e vulgarizaçăo do extermínio, Lanzmann vai defender a radical singularidade da palavra na cena documental.

4 Para um aprofundamento da problemática do testemunho diante da violência de Estado, ver os trabalhos de Márcio Seligmann-Silva, conforme bibliografia. 
e o espaço da "extimidade" (MACEDO, 2012, p. 9): aquele espaço que, segundo a psicanálise, sendo tão próprio aos sujeitos, só poderia apresentarse fora deles, no âmbito da cultura, no âmbito da interação com o outro, no âmbito da exterioridade da linguagem.

Tomando uma contramão bastante crítica à dimensão confessional da cultura, em $O$ s dias com ele a vida da realizadora Maria Clara se revela, ao menos em alguma medida, por meio da relaçáo com um outro que, separado e jamais assimilado, efetua uma mediação incontornável. Se "filmar é filmar relaçóes, inclusive as que faltam", como também defende Comolli (2007, p.107), é porque aqui o cinema junta o que a vida separa, criando um espaço comum em que as lacunas, as distâncias e as disputas não são suprimidas, mas constitutivas da própria cena e dos sujeitos filmados, ambos permanentemente inacabados. Eis aí a força política do filme. Como sabemos, as verdadeiras experiências democráticas são aquelas que abrigam o dissenso e o desentendimento em seu interior, e não as que impóem autoritariamente um consenso.

Tal processo de separação entre quem filma e quem é filmado também pode ser observado em Santiago, de João Moreira Salles (Brasil, 2007), e em Mataram meu irmão, de Cristiano Burlan (Brasil, 2013), ambos atravessados, embora de modos muito diferentes, por distintas formas de violência e distância, das relaçóes de classe e de poder às duras relaçóes familiares e sociais. Do mesmo modo, longe da indistinção fusional e complacência narcísica, filmes recentes têm sido marcados pela ausência. Tal é o caso de Guarnieri, de Francisco Guarnieri (Brasil, 2017), cinebiografia do ator e dramaturgo Gianfrancesco Guarnieri feita por seu neto, e Iramaya, de Carolina Benjamin (Brasil, 2017), retrato da militante e avó da diretora, conhecida como "Mãe da Anistia", quem, durante a ditadura, liderou uma intensa campanha internacional para a liberação de seu filho caçula, César Benjamin, então preso. "Minha relação com meu avô foi uma espécie de 'não relação”, diz o narrador de Guarnieri no início do filme, ao comentar uma foto em que aparece sentado perto do avô, mas separado por uma distância física que o neto agora tenta explicar. "Você estava lá, com sua presença ausente, assim como nesse filme que eu faço para você, sem você”, profere a voz de Carolina Benjamin ao pai, ao se deter sobre o único vídeo de família (uma festa infantil) que tem de sua infância. No primeiro, Gianfrancesco Guarnieri não está mais vivo para dar seu depoimento sobre a relação entre arte, política e o privilégio da ação pública em detrimento dos interesses familiares ou particulares. Do segundo, César Benjamin, filho de Iramaya e pai de Carolina, se recusa a participar e a testemunhar, instaurando um vazio no centro do filme.

Ao comentar sua trajetória crítica no belíssimo texto "O travelling de Kapo”, não por acaso o crítico Serge Daney assim definiria sua relação com 
o cinema: "E o cinema, vejo muito bem porque o adotei: para que ele me adotasse de volta. Para que ele me ensinasse a perceber, incansavelmente pelo olhar, a que distância de mim começa o outro."

\section{Testemunho, documento e política}

- Eu queria falar um pouco sobre a questão da tortura - diz Maria Clara a Escobar

- O quê? Da cultura?

- Da tor-tu-ra!

Walter Benjamin escreveu em seu último texto, "Sobre o conceito de história", que nunca existiu um documento da cultura que não fosse, ao mesmo tempo, um documento da barbárie (1996, p. 225). Não à toa, o ato falho de Carlos Henrique Escobar, que escuta "cultura" no lugar de "tortura", diz respeito ao reconhecimento dessa violência que está na origem dos processos culturais e civilizatórios. Essa violência, que Os dias com ele figura e coloca em cena, é preciso lembrar, diria ainda respeito ao próprio cinema. Nesse sentido, o "ele" do título não se refere apenas, com distância, ao pai e ao intelectual, ao personagem que quer intervir no processo do filme, mas também ao próprio fazer cinematográfico, dada a extrema consciência de que filha e pai, realizadora e personagem, têm do filme que está sendo feito, do filme em disputa. Os dias com ele referem-se também aos dias com o cinema.

Em alguns momentos, Maria Clara pede que Escobar testemunhe a sua experiência da tortura. Ele tergiversa, cita Derrida, que pensou a condição impossível do testemunho, sobretudo na cena do tribunal, "uma cena falsa", e diz que vai falar sobre o que significou a tortura para si. Então Maria Clara faz um zoom in e Escobar chacoalha as pernas inquieto, como a se preparar para o seu testemunho, mas finalmente, sem muito hesitar, segue teorizando. Ele não fala, não consegue narrar. É só quando Maria Clara, mais tarde, lembra a ele de que sua peça $A$ paixão do marxismo começa com a descrição de uma tortura (a que teria sofrido Althusser), que Escobar é capaz de se aproximar da experiência traumática. Como se pode perceber, ele precisa da ajuda da ficção para voltar ao momento em que o "cristal se partiu" e "o horror e a revolta se tornaram furor e desordem". Aqui, a imaginação, como argumenta Marcio Seligmann-Silva (2008, p.70), é chamada "como arma que deve vir em auxílio do simbólico para enfrentar o buraco negro do real do trauma”, o qual encontraria na imaginação um meio para sua narração.

Em outro momento do filme, quase ao final, Maria Clara pede que Escobar se sente em uma cadeira vazia no quintal da casa onde vive, para que ele leia diante da câmera um documento do DOPS (Departamento de Ordem Pública e Social) com seu mandado de prisão em 1973, um dos momentos 
mais intensos da repressão. Escobar se recusa. Para ele, o documento é a expressão da burocracia, um arquivo morto, que só glorificaria o torturado, individualizando-o, e daria voz aos torturadores. "Há crimes imensos e incríveis, mas isso todo mundo sabe. E fica meio insípido ler a prisão de um cara quando foram presos 10 mil”, ele argumenta de maneira combativa à Maria Clara, ambos fora de quadro e no antecampo (o espaço da câmera), enquanto a cadeira permanece vazia. Maria Clara tenta argumentar, mas Escobar continua. Diz que a filha "talvez não saiba direito quem está filmando" e que sua saída seria "fazer uma coisa estética, não um documento", caso contrário tudo resvalará para uma obra "boba e narcísica".

Sustentando sua posição crítica ao filme que está sendo feito, Escobar acrescenta ainda com um misto de lucidez aguda e vaidade incontrolável: "Não me tome como alguém que você possa usar secundariamente, porque o que eu tenho de melhor encheria o filme”. Como fica claro, ele não quer ser um "personagem secundário" no filme da filha, ela que sempre foi secundária em sua vida diante dos grandes ideais políticos. Nessa disputa por protagonismo, Maria Clara reage com insubordinação e teimosia, ao final sentando, por assim dizer, na cadeira vazia do "inimigo" - espécie de figuração do próprio lugar paterno e de seu mandado de prisão pelos militares. Teria Maria Clara aprendido a desobediência com o pai? Seria essa a sua herança? Num gesto ambíguo, Maria Clara acaba por fazer um elo com Escobar, em uma situação que aparentemente estava destinada ao conflito.

Essa sequência, sintomática da relação entre pai e filha, nos leva a pensar que se o Real só pode ser pensado como um "desencontro", como aquilo que, conforme a psicanálise, não pode ser simbolizado pela linguagem, não deixa de ser verdade que o cinema em geral e o documentário em particular buscam este encontro impossível, mesmo que por meio do confronto 5 . O cinema tenta, assim, juntar o que a própria vida separa, o pai e a filha, pois só haveria proximidade verdadeira quando há reconhecimento da estranheza e da estrangeiridade em sua radicalidade não camuflada. Nessa ética da distância e do reconhecimento da alteridade, nessa "ética do inimigo", portanto, que se desvencilha da ideia de posse do outro para, longe de toda indistinção fusional, dar lugar ao reconhecimento do não idêntico, estaria a dimensão política tão evidente de Os dias com ele. Retomando Jeanne Marie Gagnebin, em Lembrar, escrever, esquecer, precisaríamos dizer "não à frase: somos todos um, mas sim: somos estrangeiros uns aos outros - esta seria uma frase de humanidade" (2006, p. 94).

5 Não por acaso o documentarista Eduardo Coutinho costumava dizer que "o documentário tem como tema a impossibilidade de se chegar ao real" e que "nenhum filme filma a verdade", mas documenta um encontro entre o cineasta e o mundo, em que "a palavra é um elemento essencial da relaçáo". Ver o volume de entrevistas organizado por Felipe Bragança, Eduardo Coutinho. Rio de Janeiro: Azougue, 2008, p. 110; 111;193. 
Também é preciso acrescentar que Os dias com ele não trata da memória como depositária de algo que ficou no passado, mas como algo que emerge, que retorna, que irrompe no âmago do próprio presente. Algo de difícil transmissibilidade. De natureza extremamente processual e ancorado no presente da relação e da filmagem, condição que o difere de Diário de uma busca, os momentos mais cativantes de $O$ s dias com ele sáo aqueles em que Escobar, entre a desconfiança das intenções da filha e a segurança em sua própria performance, crê que a câmera ainda não está ligada e se prepara para ser filmado, ora roteirizando e encenando suas falas, ora questionando e colocando em xeque as perguntas e os propósitos da filha. Sem dúvida, as estratégias documentais de Maria Clara implicam questóes éticas de difícil decisão, já que nesse campo não há regra ou norma geral. É apenas no corpoa-corpo das relaçóes pessoais e no um-a-um da relação com os filmes que se pode decidir e tomar uma posição. Estamos diante, assim, de uma beleza doída e irreconciliada, em que só se pode partilhar uma experiência, por meio de uma língua sempre estrangeira, pelo que há nela de intransferível, incompreensível e, no limite, impossível.

Em Os dias com ele, a política é efetivada, portanto, pela ética da distância e do reconhecimento da alteridade, assim como pela dimensão processual, inacabada e dissensual do filme, sempre aberto e ameaçado pelo risco de sua não realizaçáo, pelo risco do fracasso. Como já argumentamos em outras ocasióes $^{6}$, são inúmeros, aliás, os documentários brasileiros atravessados pela ausência, pelo luto e pelo fracasso, seja do próprio filme, das relações com o outro filmado ou do movimento da história. Na contramão da permanente demanda por sucesso e otimizaçáo da performance que pauta nossas vidas, o fracasso no documentário pode também operar como um exitoso modo de criação e produção, fazendo da consciência de seus limites, da linguagem como defasagem e subtração, da cena como espaço de solidão e não realização, e da própria separação (entre realizador e personagem) a condição mesma de toda relaçáa. Assim, o risco do fracasso apontaria para uma abertura ao novo, para uma disposição a novas possibilidades de invenção.

\section{Esse não é o meu pai}

"Esse não é o meu pai" - diz a voz off de Maria Clara sobre filmes domésticos em Super-8, imagens caseiras de pais com seus filhos em situaçóes cotidianas ou de férias, onde veem-se praia, piscina, amor e cuidados. Ao

6 Ver nosso trabalho "O êxito do fracasso: notas sobre o documentário brasileiro contemporâneo / The Success of Failure: notes on contemporary Brazilian cinema". In: BRASIL, André (Org.) Teia $2002-$ 2012. Belo Horizonte: Teia, 2012, ou ainda "O fracasso como produção: sobre o documentário brasileiro contemporâneo”. In: DUNCKER, Christian; RODRIGUES, Ana Lucília (Orgs.) Cinema e Psicanálise, vol. IV. São Paulo: nVersos, 2014. 
contrário dos empregos usuais desse tipo de material, essas imagens não vêm ilustrar ou elucidar a infância da realizadora, sendo antes uma espécie de "memória emprestada" (expressão que seria originalmente o próprio título do filme) a preencher as lacunas e a ausência de seu pai em sua infância. Como esclarece Carla Maia, no texto que acompanha o DVD do filme, "o arquivo doméstico em Os dias com ele é índice de um vazio, ocupa o lugar das imagens que faltam, da memória que falta". Para ela, as imagens em Super-8 operam "uma passagem do um ao qualquer um, do pai ao anônimo, do íntimo ao estranho, da história pessoal à história pública”, num jogo entre a primeira e a terceira pessoa.

Tal passagem da história pessoal à coletiva também pode ser vista em Diário de uma busca, onde a luta pela utopia vai, com o passar dos anos, dando lugar a uma profunda melancolia por parte de Celso Castro. Em determinada carta (lida em voz off pelo irmão de Flávia), Celso diz, sobre a imagem da porta do Aeroporto Internacional do Galeão, no Rio de Janeiro, vista de dentro:

Sábado fui a uma festa do comitê de Anistia, mil pessoas, a maioria de retornados. Uma festa surrealista, uma alegria que me pareceu chocante, um entusiasmo indecente e um toque de nostalgia melodramática. As pessoas fazem comparaçóes absurdas entre a vitória sandinista e a volta dos exilados. Parece que ninguém se dá conta, e o que é pior, ninguém quer entender que voltamos derrotados, que houve uma concessão da ditadura e que se nos permitiram voltar é porque nos derrotaram, e se houve uma abertura é porque eles foram os vitoriosos.

Diante desse desabafo lúcido e contundente, ainda que imensamente triste, pela primeira vez no filme não há movimento de câmera durante a leitura de uma carta de Celso. No lugar dos travellings, que acompanhavam anteriormente o movimento de suas ideias e de seu ânimo, agora ele está paralisado - e ainda dentro do aeroporto -, como quem olha para a porta de vidro fechada. Celso sabe, à maneira benjaminiana, assim como também sabe Carlos Henrique Escobar, que ele não é uma vítima da história, mas um "vencido" (TRAVERSO, 2005, p.16). Porém, diferentemente de Escobar, Celso sucumbiu à melancolia, à sensação de ausência de lugar social e subjetivo na nova repactuação brasileira posta em marcha pela Lei da Anistia, que prescreveu os crimes de Estado, legando-os a um recalcamento institucionalizado. "Não tenho mais aquele empurre de antes. Não me passa mais pela cabeça formar um grupo político. (...) Não vou conseguir. Para mim não foi possível”, diz Celso em sua penúltima carta.

Seria a melancolia um sentimento político? Nasceria ela da derrocada das ideologias ou da esperança amarga pelo porvir?, pergunta-se o historiador Enzo 
Traverso em Mélancholie de gauche [Melancolia de esquerda] (2016). Muitas décadas antes, a ambivalência do discurso e do desejo melancólico era descrita por Freud (2011) como uma dificuldade de abandono e desligamento de um objeto perdido. Para o melancólico, a perda do objeto ou do ser amado não é apenas a perda de algo, mas sobretudo a perda do lugar que o sujeito ocupava junto a isso que foi morto. Por isso, sem conseguir consentir com a perda e fazer o luto, o melancólico sucumbe. Seja como for, os duros e desesperançados diagnósticos de fracasso e esvaziamento do processo democrático brasileiro feitos por Celso Castro e Carlos Henrique Escobar - o primeiro através de sua antepenúltima carta no filme, o segundo autoexilando-se em Portugal no começo da Era Lula -, não poderiam ser mais atuais no Brasil de hoje.

\section{Precariedade e luto}

"Os filmes são sempre sobre nós", diria Maria Clara Escobar ao ser questionada se estaria fazendo um filme sobre si própria. Mas quem será esse "nós"? Nós que sabemos sempre tấo pouco e que podemos, talvez a partir de uma posição feminina, assumir nosso não saber? De fato, nem Maria Clara nem Flávia Castro conseguem respostas satisfatórias para as suas perguntas. Nunca conheceremos as circunstâncias da morte de Celso Castro dentro do apartamento de um suposto colaborador nazista no Rio Grande do Sul em meados dos anos 1980. Em plena, e igualmente suposta, abertura democrática, a polícia deu cabo de documentos, e a perícia, junto ao médico legista, manipularam as condiçóes de seu assassinato. Uma conhecida história que se repete com ares de romance policial, porém onde nunca se chega à verdade. Já Carlos Henrique Escobar, sobrevivente de dezenas de prisóes políticas, após horas de conversa, não hesita em dizer à filha: "Você não me conhece". Em ambos os filmes, a opacidade e a precariedade da compreensão estão instaladas.

Tratando dos descaminhos do país e do trauma da segunda geração, os filhos dos militantes que cresceram marcados pela ausência e pelo exílio, $O s$ dias com ele não é, como pudemos ver até aqui, um filme sobre a superação de uma filha traumatizada pelo abandono do pai, nem sobre a superação de um pai traumatizado pela tortura e pelo extravio de seu projeto revolucionário. Tampouco é um filme que demanda reparação, como tantos filmes testemunhais cujo limite de ação é o gesto da denúncia. $\mathrm{Na}$ impossibilidade de superação e de reparação, Os dias com ele é um filme sobre a separação, sobre a potência e a beleza de uma relação não conciliada (entre dois seres próximos e estrangeiros), que, ainda assim, acolhe o afeto e o enlace. Se o pessoal é político, entre o pai e o país, o eu e o outro, temos aqui a evidência de que a memória não se faz sob o signo da sucessão e da herança, e sim da disputa e do laço.

Ao reconhecer nossa "vulnerabilidade constitutiva", como defende Judith Butler (2016), e demandar uma "estética do impossível" que possa fazer 
frente à impotência dos traumas, históricos e pessoais, como postula Alain Badiou (2004), tanto Os dias com ele como Diário de uma busca compreendem a precariedade como um modo de narração da experiência da segunda geração e sustentam a necessidade do luto. Mas como passar do reconhecimento da precariedade ao luto? Para Butler, a condição vulnerável conduziria à potência, a uma forma de saber que acolhe a dimensão sempre impossível do encontro com o Real, em vez do lugar fácil da queixa e da vitimização, ao qual seria muito fácil aderir (de uma filha supostamente rejeitada a um pai amargurado). Por isso, segundo a filósofa, demandar reconhecimento não implica pedir que se reconheça o que cada um já é, mas invocar um devir, estar à espreita de uma transformação, exigir um futuro. E náo há futuro sem luto: como se sabe, só o trabalho de luto, por todos aqueles que desapareceram, por todas as utopias perdidas e ideais extraviados, pode reinventar um novo projeto de país, colocando a vida em movimento.

Por isso, se de um lado "esse não é o meu pai" é um enunciado privado, emitido por aquela que ainda se julga um "personagem secundário", de outro "esse não é o meu pai" é um enunciado coletivo e político, já que todos aqueles anônimos a figurar em filmes de família caseiros poderiam ser seu pai. Como é possível notar, a partir de uma posição feminina, posição tradicionalmente subalterna ${ }^{7}$ que permitiria a fala de personagens secundários, o trabalho do luto pode ser feito. Assim, tanto a cadeira vazia como as imagens que faltam não precisam ser, a todo custo, preenchidas.

7 A problemática da subalternidade ligada à questáo colonial e de gênero, desenvolvida nos anos 1980 pela teórica indiana Gayatri Spivak em Pode o subalterno falar? (UFMG, 2010), encontra fortes ressonâncias nos debates e polêmicas em curso no Brasil hoje, como se vê nos recentes lançamentos de $O$ que élugar de fala?, da mestre em Filosofia política e feminista negra Djamila Ribeiro (Letramento, 2017) e de $A$ vítima tem sempre razãoa?, do ensaísta Francisco Bosco (Todavia, 2017). 


\section{Referências bibliográficas}

ARFUCH, Leonor. O espaço biográfico - dilemas da subjetividade contemporânea. Trad. Paloma Vidal. Rio de Janeiro: EdUERJ, 2010.

BADIOU, Alain. "Por uma estética da cura analítica". A psicanálise \& os discursos. Trad. Analúcia Teixeira Ribeiro. Rio de Janeiro: Escola Letra Freudiana, n. 34/35, ano XXIII, 2004, p. 237-242.

BARRENHA, Natalia; PIEDRAS, Pablo. "Silêncios históricos e pessoais". Catálogo da mostra "Silêncios históricos e pessoais - memória e subjetividade no documentário latino-americano contemporâneo". Caixa Cultural São Paulo, de 26 de março a 06 de abril de 2014 .

BENJAMIN, Walter. "Sobre o conceito da História". In: Obras escolhidas. Magia e técnica, arte e política. Trad. Sergio Paulo Rouanet. Sáo Paulo: Brasiliense, 1994.

BUTLER, Judith. Problemas de gênero - feminismo e subversão da identidade. Rio de Janeiro: Civilizaçáo Brasileira, 2003.

BUTLER, Judith. "Vidas precárias". In: Quadros de guerra: quando a vida é passivel de luto? Trad. Sergio Lamarão e Arnaldo Marques da Cunha. Rio de Janeiro: Civilização Brasileira, 2016.

COMOLLI, Jean-Louis. "Como filmar o inimigo?". In: Ver e poder: a inocência perdida - cinema, televisão, fiç̧ão, documentário. Trad. Augustin de Tugny, Oswaldo Teixeira e Ruben Caixeta. Belo Horizonte: UFMG, 2008.

COMOLLI, Jean-Louis. "Os homens ordinários. A ficção documentária”. In: O comum e a experiência da linguagem. GUIMARÃES, C.; OTTE, G.; SEDLMAYER, S. (Orgs.) Belo Horizonte: UFMG, 2007.

DANEY, Serge. "O travelling de Kapo". In: Revista de Comunicação e Linguagens, n²3. Lisboa, Ediçóes Cosmos, 1996.

ESCOBAR, Maria Clara. "Anotaçôes sobre um processo". Livreto que acompanha o DVD de "Os dias com ele". Rio de Janeiro: Instituto Moreira Salles, 2015.

FELDMAN, Ilana. "Do pessoal ao político", a respeito do filme "Os dias com ele", de Maria Clara Escobar. Coluna "Ponto Crítico", caderno Ilustríssima, Folha de S. Paulo, em 20 de março de 2016.

FELDMAN, Ilana. "O êxito do fracasso". In: Jogos de cena: ensaios sobre o documentário brasileiro contemporâneo. Tese de Doutorado apresentada ao Programa de PósGraduação em Ciências da Comunicação da Escola de Comunicaçóes e Artes da Universidade de São Paulo, ECA/USP, 2012.

FREUD, Sigmund. Luto e melancolia. Trad. Marilene Carone. São Paulo: Cosac Naify, 2011.

FUENTES, Maria Josefina Sota. As mulheres e seus nomes, Lacan e o feminino. São Paulo: Scriptum, 2012. 
GAGNEBIN, Jeanne Marie. "Ética e estética no pensamento de Adorno”. In: Lembrar, escrever, esquecer. São Paulo: Ed.34, 2006.

KEHL, Maria Rita. Deslocamentos de feminino. Rio de Janeiro: Imago, 2008.

KEHL, Maria Rita. "Melancolia e criação”. In: FREUD, Sigmund. Luto e melancolia. São Paulo: Cosac Naify, 2011.

MACEDO, Lucíola de Freitas. “Testemunho, extimidade e a escrita de Primo Levi”, In: Rev. Let., São Paulo, v.52, n.1, p.51-65, jan./jun. 2012.

MAIA, Carla. "Hipóteses sobre Os dias com ele". Livreto que acompanha o DVD de "Os dias com ele". Rio de Janeiro: Instituto Moreira Salles, 2015.

RANCIÈRE, Jacques. O desentendimento. Trad. Ângela Leite Lopes. São Paulo: Ed. 34, 1996.

SAID, Edward. Reflexóes sobre o exílio e outros ensaios. Trad. Pedro Maia Soares. São Paulo: Cia das Letras, 2003.

SANTIAGO, Lívia. "Destinos do trauma: da representação à figurabilidade, do real traumático do feminino à ética do reconhecimento da precariedade”. São Paulo, 2015, inédito.

SARLO, Beatriz. Tempo passado - cultura da memória e guinada subjetiva. Trad. Rosa Freire d'Aguiar. São Paulo: Cia das Letras, 2007.

SELIGMANN-SILVA, Marcio (Org.). História, memória e literatura: o testemunho na era das catástrofes. Campinas: SP: Unicamp, 2006.

SELIGMANN-SILVA, Marcio . "Narrar o trauma - A questão dos testemunhos de catástrofes históricas”. In: Psicologia clínica vol.20 no.1, Rio de Janeiro, 2008.

SPIVAK, Gayatri Chakravorty. Pode o subalterno falar? Belo Horizonte: UFMG, 2010.

TRAVERSO, Enzo. Mélancholie de gauche. Paris: Éditions La découverte, 2016.

TRAVERSO, Enzo. Le passé: modes d'emploi. Histoire, mémoire, politique. Paris: La Fabrique, 2005

ZAMBRA, Alejandro. Formas de voltar para casa. Trad. José Geraldo Couto. São Paulo: Cosac Naify, 2014.

Ilana Feldman é pós-doutora em Teoria Literária pelo Instituto de Estudos da Linguagem da UNICAMP e doutora em Cinema pela Escola de Comunicaçóes e Artes da USP, com passagem pelo Departamento de Filosofia, Artes e Estética da Universidade Paris 8, tendo desenvolvido a tese "Jogos de cena: ensaios sobre o documentário brasileiro contemporâneo". Atualmente, realiza pós-doutorado no Programa d e Pós-graduação em Meios e Processos Audiovisuais da ECA-USP, com pesquisa sobre cinema, autobiografia, testemunho e luto.

E-mail: ilafeldman@gmail.com

Recebido em: 10/09/2017 Aceito em: 30/11/2017 